\title{
Efektivitas Metode Penemuan Terbimbing (Guided Discovery) Terhadap Kemampuan Penalaran Matematis Siswa Kelas V Materi Pecahan
}

\author{
Author: \\ Puput Ida Ayu Asmianti ${ }^{1}$ \\ Yhasinta Agustyarini ${ }^{2}$

\section{Affiliation:} \\ ${ }^{1}$ Institut KH. Abdul Chalim \\ Mojokerto, East Java, Indonesia \\ ${ }^{2}$ Institut KH. Abdul Chalim \\ Mojokerto, East Java, Indonesia
}

Corresponding author:

Yhasinta Agustyarini,

yhasintaagustyarini@yahoo.co

$\underline{\mathrm{m}}$

\section{Dates:}

Received: $7 / 10 / 2021$

Accepted: 21/11/2021

Published: 30/11/2021

\begin{abstract}
Abstrak. Penelitian sebelumnya menunjukkan kemampuan berpikir matematis siswa tidak sesuai dengan prediksi, maka penelitian ini terinspirasi dari temuan tersebut. Pembelajaran dengan pendekatan penemuan terbimbing merupakan salah satu pembelajaran untuk mengembangkan kemampuan penalaran matematis. Masalah penelitian ini adalah untuk melihat apakah metode penemuan terbimbing lebih efektif daripada metode konvensional dalam meningkatkan kemampuan penalaran matematis siswa. Penelitian ini menggunakan desain eksperimen semu yang menggabungkan dua jenis pembelajaran: pembelajaran penemuan terbimbing dan pembelajaran konvensional. Dalam penelitian ini, partisipan adalah siswa kelas atas di MIS Setia Bhakti Trawas Kabupaten Mojokerto. Purposive sampling digunakan, dan dua kelas dikumpulkan sebagai sampel penelitian. Sebuah ujian kemampuan penalaran matematis digunakan sebagai alat penelitian. Berdasarkan hasil penelitian dapat disimpulkan bahwa siswa yang mendapatkan pembelajaranpenemuan terbimbing lebih meningkatkan kemampuan penalaran matematisnya dibandingkan siswa yang mendapatkan pembelajaran konvensional.
\end{abstract}

Kata kunci: Metode Pembelajaran, Metode Penemuan Terbimbing, Kemampuan Penalaran Matematis

\begin{abstract}
Previous studies had shown that students' mathematical thinking abilities were not as predicted, hence this investigation was inspired by those findings. Learning with the guided discovery approach is one of the lessons to develop mathematical reasoning skills. The study's problem is to see if the guided discovery method is more effective than conventional ways in terms of improving students' mathematical reasoning ability. This research employs a quasi-experimental design that incorporates two types of learning: guided discovery learning and conventional learning. In this study, the participants were upper-class students at MIS Setia Bhakti Trawas in Mojokerto Regency. Purposive sampling was used, and two classes were collected as research samples. A mathematical reasoning ability exam was employed as the research tool.Based on the findings of the study, it was concluded that students who received guided discovery learning methods improved their mathematical reasoning abilities more than students who received conventional learning.
\end{abstract}

Keywords: Learning Method, Guided Discovery Method, Mathematical Reasoning Ability

\section{Copyright:}

JoMEaL

This work is licensed under a Creative Commons Attribution-ShareAlike 4.0 International License.

Read online:

https://jurnal.unej.ac.id/index.php/JOMEAL/index or scan barcode beside.

How to cite this article:

Asmianti, P., \& Agustyarini, Y. (2021). Efektivitas Metode Penemuan Terbimbing (Guided Discovery) Terhadap Kemampuan Penalaran Matematis Siswa Kelas V Materi Pecahan. Journal of Mathematics Education and Learning, 1(3), 287-298. doi:10.19184/jomeal.v1i3.27654 


\section{Pendahuluan}

Matematika adalah ilmu universal yang penting dalam banyak bidang pemikiran dan sains manusia dan berfungsi sebagai dasar untuk kemajuan teknologi modern. Menurut Muchlis, semua siswa harus belajar matematika untuk meningkatkan kemampuan berpikir kritis, analitis, sistematis, kritis, dan kreatif, serta berkolaborasi dengan orang lain (Effie Efrida Muchlis, 2012).

NCTM menetapkan lima kemampuan matematika yang harus dimiliki peserta didik, diawali dengan tujuan pendidikan matematika: keterampilan pemecahan masalah, keterampilan komunikasi, keterampilan koneksi, keterampilan penalaran, dan keterampilan representasi (NCTM, 2000). Kemampuan penalaran matematis merupakan kualitas yang sangat penting yang harus dimiliki peserta didik untuk menyelesaikan masalah matematika (Hidayati, 2015). Oleh karena itu, guru sudah seharusnya menjadi fasilitator yang dapat membantu dalam proses pembelajaran matematika.

Kondisi pembelajaran matematika di beberapa sekolah saat ini menunjukkan bahwa guru masih mendominasi proses pembelajaran sehingga mengakibatkan hasil belajar siswa yang kurang baik, juga masih terdapat peserta didik yang masih belum memiliki kemampuan penalaran yang kuat. Kondisi demikian banyak terjadi terjadi di beberapa sekolah di Mojokerto. Salah satunya terjadi di MIS Setia Bhakti Trawas. Hal ini sesuai dengan temuan wawancara yang dilakukan peneliti dengan salah satu guru matematika di MIS Setia Bhakti Trawas yang mengungkapkan bahwa guru membimbing kegiatan belajar mengajar, dan siswa mendengarkan, mencatat, dan mempraktekkan pertanyaan yang diberikan oleh guru, dan kemampuan siswa dalam bernalar pada mata pelajaran Matematika masih rendah (Asmianti, 2021). Hal ini sesuai dengan pendapat Suherman bahwa dalam pelaksanaan pembelajaran matematika di sekolah biasanya guru masih bersifat teacher centered yaitu guru masih mendominasi di kelas dan siswa cenderung pasif. Ini berarti bahwa anak-anak hanya akan percaya apa yang dikatakan guru kepada mereka. Jenis pembelajaran ini terutama difokuskan pada guru. Sementara kurikulum saat ini memerlukan pembelajaran yang lebih berpusat pada peserta didik untuk memenuhi harapan kemajuan pembelajaran abad ke-21.

Pembelajaran pendekatan teacher-centered itu akan berakibat pada kemampuan penalaran peserta didik. Sampai sekarang kenyataan bahwa matematika menjadi problem bagi sebagian peserta didik. Terlihat dari kualitas pada bidang matematika yang masih jauh dari harapan. Pada hasil studi Programme for international student assesment (PISA) tahun 2018 dirilis oleh OECD yaitu:

"some 28\% of student in Indonesia attained at least level 2 or hight in mathematics (OECD average:76\%). At minimum, these student can interpret and recognise, without direc instructions, how a (simple) situation can be represented mathematically ( e.g. comparing the total distance across two alternative routes, or converting prices into a different currency" (OECD, 2019).

Menurut data di atas, sekitar 28\% siswa Indonesia berada di level 2, dibandingkan dengan rata-rata OECD sebesar 76\%. Tanpa instruksi langsung, siswa setidaknya dapat menafsirkan dan mengenali. Saat mengerjakan soal PISA, siswa membuat $16 \%$ kesalahan dalam memahami soal, 74,25\% kesalahan dalam memahami konsep, 62,81\% kesalahan dalam menggunakan operasi aritmatika, dan 67,58\% kesalahan dalam interpretasi. Dari data tersebut dapat disimpulkan bahwa banyak siswa Indonesia yang terus berjuang dalam pelajaran matematika; Menurut data, 50\% siswa masih kesulitan menggunakan rumus, prosedur, dan algoritma dasar untuk menjawab soal. Sehingga hasil matematika masih tergolong rendah. Gambaran dari hasil tes PISA tahun 2018 dapat dilihat pada gambar: 


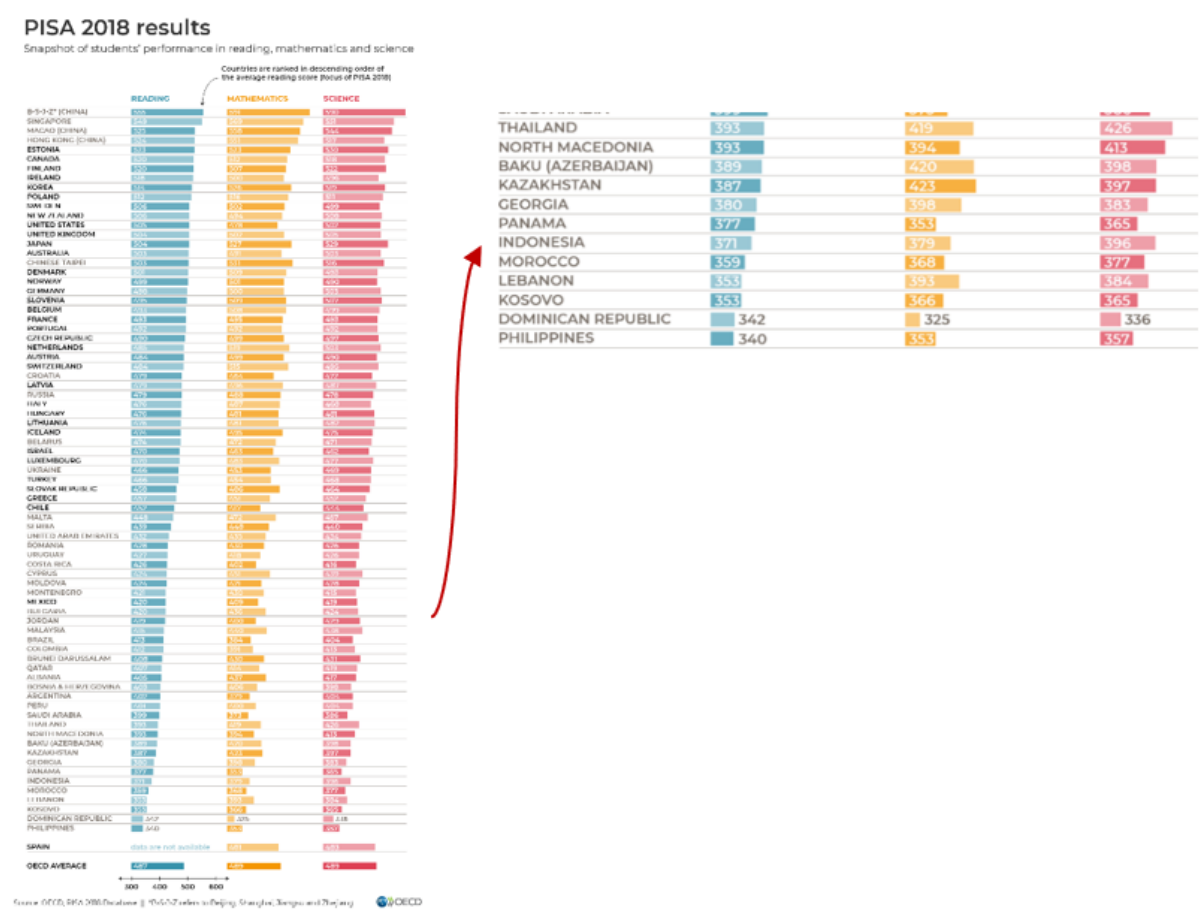

Gambar 1. Hasil PISA 2018

Rata-rata skor yang didapat Indonesia dalam bidang matematika pada tahun 2018 hanya 379, dan telah mengalami penurunan dari tahun sebelumnya. Untuk mengatasi masalah tersebut, diperlukan suatu metode untuk meningkatkan kualitas pembelajaran matematika yang unggul dan relevan bagi anak-anak memasuki abad kedua puluh satu.

Pembelajaran abad 21 merupakan unsur pembelajaran yang direkomendasikan untuk digunakan dalam pembelajaran matematika. Lajunya pertumbuhan ilmu pengetahuan dan teknologi telah mengakibatkan berbagai perubahan yang signifikan, termasuk perubahan dalam pendidikan matematika. Pembelajaran ini menekankan pada kreativitas, berpikir kritis, kolaborasi, dan keterampilan komunikasi (Murtiyasa, 2016). Selama proses pembelajaran matematika, bakat ini dapat dikembangkan dan diperkuat, dan guru dapat memanfaatkan berbagai teknik pembelajaran untuk membantu siswa memperoleh keterampilan ini. Ideologi konstruktivisme, penemuan terbimbing adalah salah satunya. Metode penemuan terbimbing memungkinkan siswa untuk berpikir sendiri, belajar dari pengalamannya, dan mengkaji materi yang disajikan kepada mereka untuk mencapai kesimpulan selama proses pembelajaran.

Banyak variabel yang berkontribusi terhadap kinerja siswa yang buruk, diantaranya kolaborasi penggunaan pendekatan pembelajaran yang kurang tepat, artinya pembelajaran yang masih dominan terkonsentrasi pada pengajar, mengakibatkan siswa menjadi peserta yang kurang aktif dalam proses pembelajaran. Salah satu faktor terpenting dalam pembelajaran adalah metode pembelajaran. Menurut Sagala, metode adalah pendekatan atau cara yang digunakan pengajar dalam proses pembelajaran untuk mengolah informasi berupa fakta, data, dan konsep (Ruminiati, 2007). Guru harus terampil memanfaatkan atau memilih teknik yang tepat dalam pembelajaran siswa.

Salah satu kegiatan belajar yang menonjolkan kegiatan berbeda adalah penggunaan metode tertentu, karena metode dalam pembelajaran pada dasarnya adalah cara yang sistematis untuk mencapai tujuan pengajaran dan memperoleh kapasitas untuk meningkatkan efisiensi pembelajaran 
yang dilakukan oleh pengajar dan siswa, diperlukan strategi pembelajaran yang tepat untuk mengantisipasi kesulitan tersebut dan meningkatkan keaktifan siswa dalam mempelajari matematika. Guru akan terus mengembangkan dan menerapkan cara pembelajaran baru untuk menciptakan lingkungan belajar yang lebih efektif dan menyenangkan. Salah satu pilihan adalah dengan menggunakan metode penemuan terbimbing.

Berdasarkan permasalahan di atas, peneliti terdorong untuk melakukan penelitian tentang "Efektivitas metode penemuan terbimbing (guided discovery) terhadap kemampuan penalaran matematis peserta didik kelas v pada mata pelajaran matematika materi pecahan di MIS Setia Bhakti Trawas"

\section{Metode Penelitian}

Metode yang diterapkan dalam penelitian ini ialah metode kuantitatif. Jenis penelitian yang digunakan dalam penelitian ini adalah menggunakan metode Quasi Experiment, yaitu metode pembelajaran dengan membuat perubahan kondisi dan mengamati pengaruhnya. Metode ini meliputi variabel dependen (terikat) dan variabel independen (Purwanto, 2013). Adapun variabel terikatnya kemampuan penalaran matematis, sedangkan variabel bebasnya adalah pembelajaran dengan metode penemuan terbimbing.

Desain yang digunakan pada penelitian ini yaitu two group pre-test - post-test, dimana ada 2 kelas yang diberikan perlakuan yang berbeda, yaitu kelas eksperimen dan kelas kontrol. Kedua kelas tersebut diberi pre-test untuk mengetahui keadaan awal, apakah ada perbedaan antara kelas eksperimen dan kelas kontrol. kemudian kedua kelas tersebut diberi perlakuan yang berbeda dimana kelas eksperimen menggunakan metode penemuan terbimbing dan kelas kontrol menggunakan metode konvensional. Setelah selesai perlakuan kedua kelas tersebut diberi post-test yang bertujuan untuk mengetahui penalaran matematis peserta didik atas perlakuan yang telah diberikan. Berikut ialah rancangan penelitian yang digunakan oleh peneliti:

Tabel 1. Desain Penelitian

\begin{tabular}{|l|c|c|c|}
\hline \multirow{2}{*}{ Kelas } & \multicolumn{3}{|c|}{ Perlakuan } \\
\cline { 2 - 4 } & Pre-test & Pembelajaran & Post-test \\
\hline Eksperimen & $O_{1}$ & $X_{1}$ & $O_{2}$ \\
\hline Kontrol & $O_{1}$ & $X_{2}$ & $O_{2}$ \\
\hline
\end{tabular}

Lokasi penelitian dilakukan di MIS Setia Bhakti Trawas, Mojokerto 61375. Penelitian ini terdiri dari peserta didik kelas atas dari MIS Setia Bhakti Trawas, sebanyak 140 peserta didik dari kelas atas, Peneliti menggunakan teknik purposive sampling dan kelas yang ditentukan sebagai sampel adalah kelas V ( A dan B). Alasan pemilihan kelas tersebut ialah metode yang digunakan tepat untuk melaksanakan pembelajaran materi pecahan pada peserta didik kelas V.

Teknik pengumpulan data menggunakan data primer yaitu hasil pre-test dan post-test, wawancara dan dokumentasi, juga menggunakan data sekunder berupa hasil PISA, artikel, jurnal, dan sebagainya. Adapun uji yang digunakan berupa instrumen penalaran matematis yang terdiri dari 10 soal essay yang telah divalidasi dan dihitung tiap analisis butir soal menggunakan validitas, reliabilitas, tingkat kesukaran, dan daya pembeda. 
Berdasarkan data yang diperoleh dari nilai pre-test dan post-test kemudian dilakukan proses dengan menggunakan uji statistik dengan bantuan aplikasi SPSS. Dalam penelitian ini tahapan analisis yang digunakan adalah:

a. Memberikan skor jawaban peserta didik sesuai dengan kunci jawaban dan kriteria penskoran yang digunakan.

b. Membuat tabel skor pre-test dan post-test peserta didik kelas eksperimen dan kelas kontrol.

c. Menghitung hasil pre-test dan post-test

Dari data yang didapat dari skor pretest dan posttest, kemudian dilakukan proses dengan uji statistik dengan bantuan aplikasi SPSS. Dalam penelitian ini tahap analisis yang digunakan yaitu: analisis deskripsi, uji normalitas, uji homogenitas, uji pair sample T-Test, dan Independent sample TTest dan Uji N-Gain

1) Analisis Deskripif

Analisis deskriptif berguna untuk memaparkan dan menggambarkan data penelitian, mencakup jumlah data, nilai maksimal, nilai minimal, rata-rata, dan sebagainya.

2) Uji Normalitas

Uji normalitas digunakan untuk mengetahui apakah data penelitian berdistribusi normal atau tidak, data normal merupakan syarat mutlak sebelum melakukan analisis statistik parametrik. Jika taraf signifikan > 0,05 maka data tersebut berdistribusi normal dan dapat melakukan analisis statistik parametrik.

3) Uji Paired Sample T-Test

Sampel berpasangan Uji Paired digunakan untuk mengetahui ada tidaknya perbedaan pengaruh metode penemuan terbimbing terhadap kemampuan penalaran matematis, serta untuk membandingkan sebelum dan sesudah terapi metode penemuan terbimbing pada siswa kelas V MIS Setia Bhakti Trawas .

4) 4) Uji Homogenitas

Uji Homogenitas adalah pengujian tentang sama tidaknya variansi-variansi dua buah distribusi atau lebih. Jika taraf signifikan > 0,05 maka data tersebut homogen, begitu pun sebaliknya. Uji homogenitas biasanya digunakan sebagai syarat untuk uji independent sampel t-test

5) 5) Uji independent Sample T-Test

Uji Independent Sample T-test digunakan untuk mengetahui ada tidaknya perbedaan yang signifikan antara dua sampel. Aturan untuk uji ini adalah bahwa data harus berdistribusi normal dan homogen (tidak mutlak), uji tersebut berasal dari hasil dua post-test yang tidak berpasangan.

6) Uji N-Gain

Uji N-Gain digunakan untuk menilai efisiensi metode penemuan terbimbing terhadap kemampuan penalaran matematis siswa, khususnya peningkatan kemampuan penalaran matematis siswa setelah diberikan perlakuan. Kenaikan ini berasal dari hasil pre-test dan post-test siswa. Rumus untuk uji N-Gain adalah sebagai berikut: (Richard R Hake, 1999)

$$
N-\text { Gain }=\frac{\text { Skor } \text { Posttest-Skor Pretest }}{\text { Skor Optimal-Skor Pretest }}
$$

Keterangan : Skor optimal adalah nilai maksimum yang diperoleh. Adapun ukuran perolehan nilai $N$-Gain adalah sebagai berikut : (Richard R Hake, 1999) 
Tabel 2. Kategori N-Gain

\begin{tabular}{|c|c|}
\hline Nilai N-Gain & Kategori \\
\hline $\mathrm{g}>0,7$ & Tinggi \\
\hline $0,3 \leq \mathrm{g} \leq 0,7$ & Sedang \\
\hline $\mathrm{g}<0,3$ & Rendah \\
\hline
\end{tabular}

\section{Hasil dan Pembahasan}

Dalam penelitian ini, Metode Penemuan Terbimbing dipakai sebagai metode dalam pembelajaran di kelas yang dilaksanakan dengan pertemuan 4 x 35 menit. Dalam proses pembelajaran peneliti mengawali pembelajaran dengan permasalahan sehari-hari yang biasanya dijumpai oleh peserta didik. Dalam hal ini, peserta didik dituntut aktif saat pembelajaran berlangsung, dimana peserta didik diminta untuk mendemonstrasikan permasalahan yang diberikan dalam menyelesaikan masalah pada lembar kegiatan siswa (LKS) dan media yang disediakan oleh peneliti. Pada awal pembelajaran diterapkannya pembelajaran dengan Penemuan Terbimbing peserta didik terlihat antusias, namun tujuan pembelajaran belum dapat dicapai secara maksimal karena peserta didik belum terbiasa dalam memberikan solusi pada masalah yang sering ditemukannya pada kehidupan sehari-hari dengan cara diskusi, sehingga pada pertemuan selanjutnya diberikan pemberian motivasi yang lebih agar siswa lebih memahami konsep dan membuat model matematika untuk masalah tertentu.

Pada hari kedua, peserta didik diajak untuk menemukan rumus penjumlahan dan pengurangan pecahan melalui kegiatan menempelkan potongan-potongan kertas hasil pecahan sehingga peserta didik dapat mengetahui rumus tersebut, kemudian peserta didik diminta untuk membuat kesimpulan tentang bagaimana cara menemukan rumus penjumlahan dan pengurangan pecahan. Melalui kegiatan tersebut peserta didik menjadi lebih paham ketika dilakukan tanya jawab seputar penjumlahan dan pengurangan pecahan. Pembelajaran juga dilakukan dengan cara diskusi dan mencari jawaban dengan anggota kelompok sehingga karakteristik "konstruktivisme" dalam penemuan terbimbing dapat terpenuhi. Peserta didik juga diajak melakukan diskusi tentang penerapan materi pecahan dalam permasalahan sehari- hari.

Penalaran matematis merupakan salah satu keterampilan yang dibutuhkan untuk menguasai matematika. Dalam penelitian ini, alat yang digunakan untuk menilai keterampilan ini adalah soal esai sebanyak sepuluh soal, dalam soal ini terdapat lima aspek dalam penalaran dan telah divalidasi, sehingga bisa mengukur variabel kemampuan penalaran matematis peserta didik pada saat sebelum dan sesudah dilakukan penemuan terbimbing.

Setelah di analisis pada kisi-kisi tes dalam penelitian ini, semua soal yang berisi 10 butir soal telah sesuai dengan syarat tes. Tes ini kemudian digunakan untuk mengumpulkan informasi tentang kemampuan bernalar matematis siswa. Tabel berikut merangkum temuan analisis:

1. Uji Validitas

Tabel 3. Hasil Uji Validitas

\begin{tabular}{|c|c|c|c|}
\hline No. Butir Soal & rhitung & rtabel $5 \%$ & Kriteria \\
\hline 1 & 0,5598 & \multirow[t]{6}{*}{0,497} & Valid \\
\hline 2 & 0,8507 & & Valid \\
\hline 3 & 0,9029 & & Valid \\
\hline 4 & 0,5292 & & Valid \\
\hline 5 & 0,7774 & & Valid \\
\hline 6 & 0,6705 & & Valid \\
\hline
\end{tabular}




\begin{tabular}{|c|c|c|c|}
\hline 7 & 0,9138 & \multirow{5}{*}{} & Valid \\
\hline 8 & 0,9310 & & Valid \\
\hline 9 & 0,9138 & & Valid \\
\hline 10 & 0,8332 & & Valid \\
\hline
\end{tabular}

2. Uji Reliabilitas

Tabel 4. Hasil Uji Reliabilitas

\begin{tabular}{|c|c|c|}
\hline Analisis & Hasil & Kategori \\
\hline $\mathrm{N}$ & 10 & Sangat Tinggi \\
\hline $\mathrm{r}_{11}$ & 0,921998 & \\
\hline
\end{tabular}

3. Uji Tingkat Kesukaran

Tabel 5. Hasil Uji Tingkat Kesukaran

\begin{tabular}{|c|c|c|c|c|}
\hline No Soal & Rata-rata & $\begin{array}{c}\text { Skor } \\
\text { Maksimum }\end{array}$ & TK & Kategori \\
\hline 1 & 7,0 & \multirow{10}{*}{10} & 0,7 & Mudah \\
\hline 2 & 8,928 & & 0,8928 & Mudah \\
\hline 3 & 8,0 & & 0,8 & Mudah \\
\hline 4 & 9,571 & & 0,9571 & Mudah \\
\hline 5 & 6,071 & & 0,6071 & Sedang \\
\hline 6 & 7,142 & & 0,7142 & Mudah \\
\hline 7 & 8,928 & & 0,8928 & Mudah \\
\hline 8 & 8,0 & & 0,8 & Mudah \\
\hline 9 & 8,928 & & 0,8928 & Mudah \\
\hline 10 & 7,928 & & 0,7928 & Mudah \\
\hline
\end{tabular}

4. Uji Daya Pembeda

Tabel 6. Hasil Uji Daya Pembeda

\begin{tabular}{|c|c|c|}
\hline No & Daya Pembeda & Kriteria \\
\hline 1. & 0,3714 & Cukup \\
\hline 2. & 0,2142 & Sedang \\
\hline 3. & 0,3714 & Cu kup \\
\hline 4. & 0,0857 & Buruk \\
\hline 5. & 0,1571 & Buruk \\
\hline 6. & 0,4857 & Ba ik \\
\hline 7. & 0,2142 & Sedang \\
\hline 8. & 0,4 & Baik \\
\hline 9. & 0,2142 & Sedang \\
\hline 10. & 0,4142 & Ba ik \\
\hline
\end{tabular}

Berdasarkan tabel di atas, dan setelah berbagai pengujian item, dimungkinkan untuk menentukan bahwa semua item sesuai dengan spesifikasi dan memenuhi karakteristik yang diprediksi. Sehingga soal-soal ujian tersebut dapat digunakan untuk menilai kemampuan penalaran matematis siswa dalam penelitian ini.

Hipotesis dalam penelitian ini yaitu kemampuan penalaran matematis peserta didik yang diajarkan dengan model Penemuan Terbimbing lebih baik dari kemampuan penalaran matematis 
peserta didik dengan pembelajaran konvensional di kelas $\mathrm{V}$ pada materi penjumlahan dan pengurangan pecahan. Untuk menguji hipotesis tersebut peneliti menggunakan aplikasi SPSS.

Data dari instrumen penelitian kemudian ditransformasikan ke dalam tabel deskriptif statistik dengan mencari (X max) dan (X min) pada data pre-test dan post-test. Kemudian periksa mean (X), modus (Mo), range $(\mathrm{R})$, dan standar deviasi (S). Tabel berikut menunjukkan hasil dari perhitungan ini:

Tabel 7. Analisis Deskriptif

Descriptive Statistics

\begin{tabular}{|l|l|r|r|r|r|}
\hline & N & Minimum & Maximum & Mean & Std. Deviation \\
\hline PreEks & 23 & 56 & 77 & 67.96 & 6.278 \\
PostEks & 23 & 80 & 92 & 85.52 & 3.502 \\
PreKon & 24 & 55 & 84 & 67.46 & 7.157 \\
PostKon & 24 & 67 & 89 & 78.13 & 5.367 \\
Valid N (listwise) & 23 & & & & \\
\hline
\end{tabular}

Data tersebut kemudian diperiksa dengan menggunakan Paired Sample T-Test untuk menguji hipotesis ini. Data sampel berpasangan harus didistribusikan secara teratur, yang merupakan salah satu persyaratan pengujian. Oleh karena itu, dilakukan uji normalitas dengan SPSS pada data pre-test dan post-test untuk memastikan bahwa data tersebut normal. Tabel berikut menunjukkan uji normalitas data pre-test dan post-test kemampuan penalaran matematis siswa:

Tabel 8. Uji Normalitas

Tests of Normality

\begin{tabular}{|l|l|r|r|r|r|r|r|}
\hline \multirow{2}{*}{} & \multirow{2}{*}{ Kelas } & \multicolumn{3}{|c|}{ Kolmogorov-Smirnov } & \multicolumn{3}{|c|}{ Shapiro-Wilk } \\
\cline { 2 - 7 } & \multicolumn{1}{|c|}{ Statistic } & Df & \multicolumn{1}{c|}{ Sig. } & Statistic & Df & Sig. \\
\hline Hasil Belajar Peserta didik & Pre Test Eksperimen & .135 & 23 & $.200^{*}$ & .940 & 23 & .182 \\
& Post Test Eksperimen & .136 & 23 & $.200^{*}$ & .950 & 23 & .299 \\
& Pre Test Kontrol & .141 & 24 & $.200^{*}$ & .949 & 24 & .255 \\
& Post Test control & .144 & 24 & $.200^{*}$ & .973 & 24 & .748 \\
\hline
\end{tabular}

*. This is a lower bound of the true significance.

Lilliefors Significance Correction

Setelah dilakukan evaluasi normalitas data, jika hasilnya berdistribusi normal maka gunakan SPSS untuk melakukan uji paired sampel berpasangan untuk melihat apakah terdapat perbedaan ratarata dari kedua sampel berpasangan tersebut. Hasil uji sampel berpasangan ditunjukkan pada tabel:

Tabel 9. Uji Paired sample t-test

Paired Samples Test

\begin{tabular}{|c|c|c|c|c|c|c|c|c|c|c|}
\hline & \multicolumn{5}{|c|}{ Paired Differences } & \multirow[b]{3}{*}{ t } & \multirow[b]{3}{*}{ df } & \multirow{3}{*}{$\begin{array}{l}\text { Sig. (2- } \\
\text { tailed) }\end{array}$} \\
\hline & & & \multirow[b]{2}{*}{ Mean } & \multirow{2}{*}{$\begin{array}{c}\text { Std. } \\
\text { Deviation }\end{array}$} & \multirow{2}{*}{\begin{tabular}{|c|} 
Std. \\
Error \\
Mean
\end{tabular}} & \multicolumn{2}{|c|}{\begin{tabular}{|c|}
$95 \%$ Confidence Interval \\
of the Difference
\end{tabular}} & & & \\
\hline & & & & & & Lower & Upper & & & \\
\hline & PreEks & & & 7.316 & 1.526 & -20.729 & -14.401 & & 22 & .000 \\
\hline $\begin{array}{l}\text { Pair } \\
2\end{array}$ & $\begin{array}{l}\text { PreKon } \\
\text { PostKon }\end{array}$ & - & -10.667 & 5.289 & 1.080 & -12.900 & -8.433 & -9.881 & 23 & .000 \\
\hline
\end{tabular}


Berdasarkan Sig. (2-tailed) nilai 0,000<0,05 yang diperoleh dari output pair 1 dan 2, maka dapat disimpulkan bahwa terdapat perbedaan rata-rata kemampuan penalaran siswa kelas eksperimen pre-test vs post-test, berarti dapat dilihat metode ini memiliki efek sebelum dan sesudah perlakuan.

Setelah uji paired sampel berpasangan, dilakukan uji homogenitas untuk menilai apakah data tersebut homogen atau tidak, karena data yang homogen merupakan salah satu prasyarat (tetapi bukan satu-satunya kebutuhan) untuk melakukan pengujian selanjutnya, yaitu sampel independent t- test. Tabel berikut menunjukkan hasil uji homogenitas.:

Tabel 10. Uji Homogenitas

Test of Homogeneity of Variances
Hasil Belajar Siswa
\begin{tabular}{|r|r|r|r|}
\hline Levene Statistic & df1 & df 2 & Sig. \\
\hline 1.916 & 1 & 45 & .173 \\
\hline
\end{tabular}

Berdasarkan output di atas diketahui nilai Sig. (2-tailed) sebesar 0, 173>0,05 sehingga dapat disimpulkan bahwa varians data post-test kelas eksperimen dan data post-test kelas kontrol adalah homogen, dengan demikian maka salah satu syarat (tidak mutlak) dari uji independent sample t-test sudah terpenuhi. Selanjutnya ialah melakukan uji independent sample t-test untuk mengetahui apakah terdapat perbedaan rata-rata dua sampel yang tidak berpasangan, uji ini digunakan untuk menjawab apakah terdapat perbedaan rata-rata kemampuan penalaran matematis peserta didik antara metode penemuan terbimbing dengan metode konvensional. Adapun hasil uji independent sample ttest dapat dilihat pada tabel:

Tabel 11. Uji ndependent Sample t-test Independent Samples Test

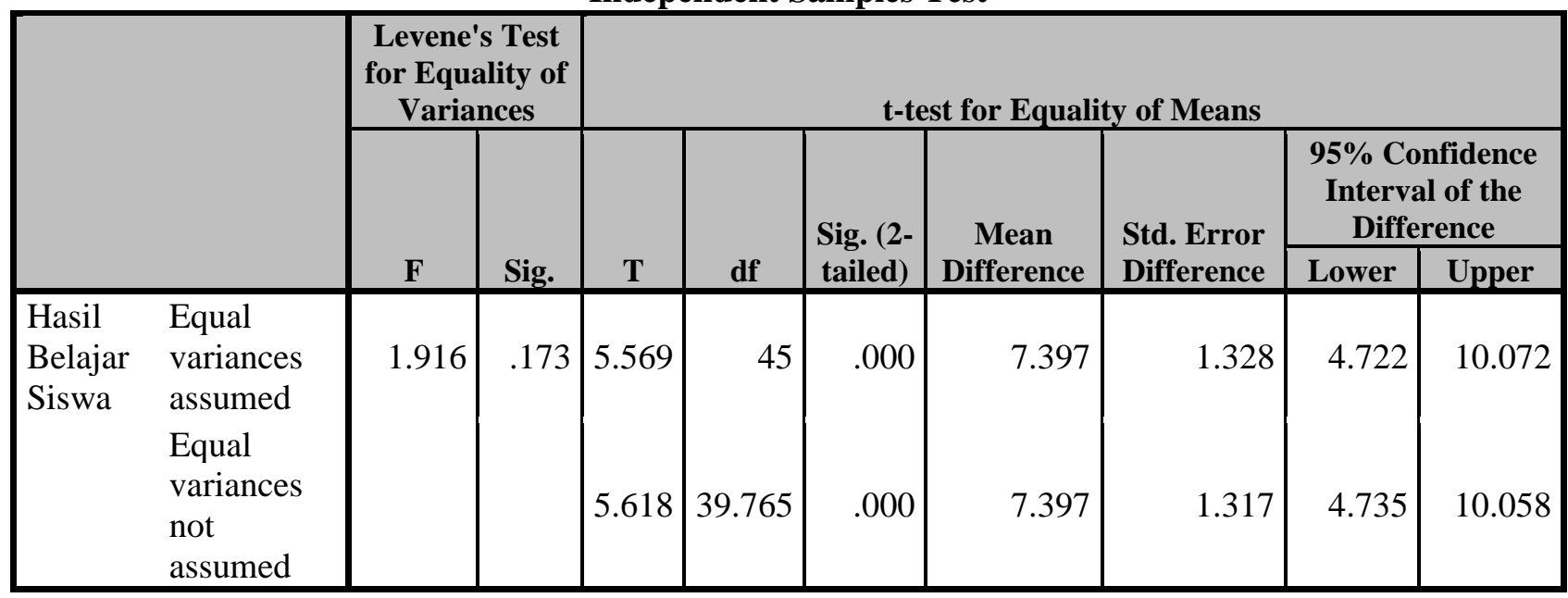

Berdasarkan output di atas diperoleh nilai Sig. (2-tailed) sebesar 0,000 < 0,05 maka dapat disimpulkan bahwa rata-rata kemampuan penalaran matematis antara metode penemuan terbimbing dengan metode konvensional terdapat perbedaan.

Uji Skor $\mathrm{N}$-Gain kemudian dianalisis untuk menilai kemanjuran menggunakan metode penemuan terbimbing. Jika uji sampel independen menunjukkan perbedaan rata-rata dari dua sampel yang tidak berpasangan, pengujian ini dapat dilakukan. Hasil uji $\mathrm{N}$-Gain ditunjukkan pada tabel: 


\section{Tabel 12. Uji N-Gain}

Berdasarkan output di atas diketahui bahwa rata-rata kelas eksperimen sebesar 0,5306 (kategori sedang) dan rata rata kelas kontrol sebesar 0,3204 (kategori sedang). Walaupun sama-sama dalam kategori sedang, namun perolehan nilai kelas eksperimen lebih tinggi daripada kelas kontrol, maka dapat disimpulkan pembelajaran dengan metode penemuan terbimbing lebih efektif dari pada metode konvensional.

Proses pembelajaran dilakukan dengan memperhatikan fitur metode penemuan terbimbing. Pembelajaran juga dilakukan dengan memperhatikan sintaks penemuan terbimbing, karena

\section{Descriptives}

\begin{tabular}{|c|c|c|c|}
\hline & Kelas & Statistic & Std. Error \\
\hline \multirow{18}{*}{ ngain_score } & 1 Mean & .5306 & .03246 \\
\hline & 95\% Confidence Interval for Mean Lower Bound & .4633 & \\
\hline & $\begin{array}{r}\text { Upper Bound } \\
\end{array}$ & .5979 & \\
\hline & $5 \%$ Trimmed Mean & .5386 & \\
\hline & Median & .5833 & \\
\hline & Variance & .024 & \\
\hline & Std. Deviation & .15566 & \\
\hline & Minimum & .20 & \\
\hline & Maximum & .71 & \\
\hline & 2 Mean & .3204 & .02690 \\
\hline & 95\% Confidence Interval for Mean Lower Bound & .2647 & \\
\hline & $\begin{array}{rc}\text { Upper Bound } \\
\end{array}$ & .3760 & \\
\hline & $5 \%$ Trimmed Mean & .3263 & \\
\hline & Median & .3636 & \\
\hline & Variance & .017 & \\
\hline & Std. Deviation & .13176 & \\
\hline & Minimum & .03 & \\
\hline & Maximum & .50 & \\
\hline
\end{tabular}

memperhatikan hal tersebut, pembelajaran selalu diawali dengan kesulitan-kesulitan dalam kehidupan sehari-hari siswa. Peneliti mendorong dan mengingatkan peserta tentang materi yang dibutuhkan, khususnya pecahan dan jenisnya, dan dari mana materi ini diperoleh sebelumnya sehingga memiliki keterkaitan materi.

Berikutnya adalah penyediaan Lembar Kegiatan Siswa (LKS) yang mendalami pengertian pecahan dalam kehidupan sehari-hari untuk membantu proses pembelajaran. Selanjutnya peneliti memberikan media berdasarkan permasalahan yang harus dijawab dalam kegiatan tersebut, sehingga siswa dapat menunjukkan secara langsung. Siswa menjadi lebih terlibat dalam memberikan kontribusi untuk pemecahan masalah matematika sebagai hasil dari kegiatan pembelajaran tersebut. Pembelajaran menjadi lebih bermakna dengan adanya media yang dapat ditampilkan.

Ciri "interaksi" terpenuhi ketika guru mengizinkan siswa untuk berbicara dan terlibat dengan rekan-rekan mereka, serta ketika guru menyambut siswa untuk mengajukan pertanyaan jika ada masalah. Siswa diminta untuk menjelaskan jawaban dari masalah berdasarkan tugas yang telah mereka selesaikan. Instruktur kemudian memperkuat hasil dari setiap percakapan kelompok dengan siswa, menghasilkan keterlibatan melalui latihan ini. Ciri "konstruktivisme" terpenuhi ketika guru 
mengizinkan siswa untuk menciptakan pengetahuan mereka sendiri, dan siswa diizinkan untuk menyimpulkan dan meramalkan jawaban atas masalah yang diberikan. Akibatnya, siswa lebih terlibat dalam studi mereka. Peneliti dalam penelitian ini berfungsi sebagai fasilitator pembelajaran dengan menyajikan masalah, menyediakan media, dan mengarahkan siswa. Proses pembelajaran dilakukan dengan berpedoman pada RPP yang memuat kegiatan-kegiatan dengan ciri penemuan terbimbing.

Data dikumpulkan dari proses pembelajaran berupa nilai pre-test dan post-test, yang kemudian dihitung dan diberikan dengan analisis deskriptif. Hasil analisis deskriptif pada kelas eksperimen menunjukkan bahwa rata-rata skor pre-test adalah 67,96 dan skor post-test adalah 85,52.

\section{Kesimpulan}

Berdasarkan analisis data dan pembahasan, temuan penelitian ini menunjukkan bahwa hasil kemampuan penalaran matematis siswa sebelum penggunaan penemuan terbimbing memiliki ratarata. 67,96. Sedangkan setelah penerapan penemuan terbimbing memiliki rata-rata sebesar 85,52, meningkat sebesar 0,5306 setelah dihitung dengan menggunakan uji $N$-Gain. Sehingga efisiensi metode penemuan terbimbing terhadap kemampuan penalaran matematis siswa kelas V MIS Setia Bhakti Trawas sebesar 0,5306 atau dalam kriteria sedang, dapat disimpulkan bahwa penemuan terbimbing memiliki pengaruh terhadap kemampuan penalaran matematis siswa kelas $\mathrm{v}$ dalam penjumlahan dan pengurangan pecahan dan lebih berhasil daripada cara konvensional. Berdasarkan kesimpulan di atas, implikasi yang dapat muncul antara lain sebagai berikut.

1. Secara teoritis, penelitian ini bersifat menguatkan teori yang sudah ada. Dengan teori terdapat pengaruh metode penemuan terbimbing untuk efisiensi kemampuan penalaran matematis peserta didik.

2. Secara praktis, penelitian ini menunjukkan bahwa untuk mengembangkan kemampuan penalaran matematis, guru harus fokus menggunakan pendekatan, model, metodologi, dan media pembelajaran yang sesuai dengan mata pelajaran yang diberikan, agar pembelajaran menjadi lebih relevan bagi siswa.

Beberapa komentar peneliti telah dibuat berdasarkan penelitian:

1. Penelitian terhadap kemampuan nalar siswa sebaiknya dilakukan dengan waktu dan sampel yang sesuai dan cukup untuk mendapatkan hasil yang lebih representatif.

2. Hal ini dimaksudkan agar mereka belajar dan menguasai lebih banyak tentang pembelajaran dengan menggunakan penemuan terbimbing dan mengenali cara-cara yang sering digunakan oleh siswa masa lalu, sehingga peneliti masa depan dapat lebih beradaptasi dan menggunakan metode penemuan terbimbing.

3. Dalam hal penelitian ini, peneliti memahami bahwa itu masih mendasar. Akhirnya, studi lebih lanjut tentang penerapan metode penemuan terbimbing harus dilakukan untuk meningkatkan pemikiran matematis siswa.

\section{Daftar Pustaka}

Badan Standar Nasional Pendidikan, Salinan PP Nomor 22 Tahun 2016, (Online), http://bsnpindonesia.org, diakses pada 10 Februari 2021

Effie, E. M. (2012). "Pengaruh Pendekatan Pendidikan Matematika Realistik Indonesia (PMRI) Terhadap Perkembangan Kemampuan Pemecahan Masalah Kelas II SD Kartika”. Jurnal Exact. Vol. X, No. 2, Desember 2012, hal 136. 
National Council of Teachers of Matematics (NCTM). (2020). Principles and Standards for School Mathematics. Reston, VA: Author, 2000, hal 29

Hidayati dkk. (2015). Proses Penalaran Matematis siswa dalam Memecahkan Masalah Matematika pada Materi Pokok Dimensi Tiga Berdasarkan Kemampuan Siswa di SMA Negeri 5 Kediri. Jurnal Math Educator Nusantara. Volume 01. No. 02, 2015, hal 132

\section{Hasil wawancara dengan guru}

OECD. (2019). Programme for International Assesment (PISA) Results from PISA 2018, Vol. IIII, 2019, Hal. 2

Saleh, H, dkk,. (2018). Analisis Kesulitan Siswa dalam Menyelesaikan soal-soal PISA (Programme for International Student Assesment) di SMP Kota Bengkulu, Jurnal Pendidikan Matematika Raflesia, Vol 03, (Bengkulu:2018), hal 180

Murtiyasa, B. (2016). Isu-Isu Kunci dan Tren Penelitian Pendidikan Matematika. Makalah. Disampaikan pada Konferensi Nasional Penelitian Matematika dan Pembelajarannya (KNPMP I) Universitas Muhammadiyah Surakarta.

Ruminiati. (2007). Pengembangan Pendidikan Kewarganegaraan SD. Jakarta. Dirjen Pendidikan Tinggi. Depdiknas. Hal 2-3

Edy, P. (2013). Metode Penelitian Kuantitatif. Semarang: Universitas Negeri Semarang, hal 103

Richard, R. H (2021). Analyzing Change/Gain Scores (Indiana:Indiana University,1999) diakses dari www.physic.indiana.edu/sdi/AnalyzingChange-gain.pdf pada tanggal 20 maret 2021 